\title{
IMPLEMENTASI PENYUSUNAN ROLE COMPETENCY PADA PERUSAHAAN MANUFAKTUR ALAT BERAT
}

\author{
Tansri Adzlan Syah ${ }^{1}$, Sovi Septania ${ }^{2}$ \\ Fakultas Psikologi Universitas Muhammadiyah Lampung \\ tansri.adzlan@gmail.com
}

\begin{abstract}
The process of adjusting to changes in the global economy raises various symptoms of problems at PT. XYZ, among others the dissatisfaction of consumers with the quality of the units produced, the emergence of employee complaints related to additional work that is responsible for his position, this causes employees to be overburdened and appear unsatisfied from employees. The problems that occur ultimately have an impact on not achieving the company's goals such as meeting customer satisfaction and decreasing company profits. The research objective is to detect and identify problems and implement it in accordance with the problems encountered. The research method used is through open system techniques using qualitative methods. The results showed the absence of a competency dictionary at PT. XYZ has a significant influence on the suboptimal management of human resources which ultimately affects the overall goals of the organization. PT. XYZ does not have a competency dictionary that can be used as a reference for moving every task and responsibility in the company. Implementation of the preparation of role competency has become one of the interventions to improve my human resource system. Evaluation Results of the implementation of the preparation of competency roles carried out by PT. XYZ evaluators considered that the guidelines and role competency were impacted to organizational needs of PT. XYZ.
\end{abstract}

Keywords: assesment, competency, organization

\begin{abstract}
ABSTRAK
Proses penyesuaian terhadap perubahan ekonomi global menimbulkan berbagai gejala permaslahan pada PT. XYZ, diantaranya tidak puasnya konsumen terhadap kualitas unit yang dihasilkan, munculnya keluhan karyawan terkait dengan pekerjaan tambahan yang tanggung jawab jabatannya, hal ini menyebabkan karyawan terbebani dan muncul tidak puasan dari karyawan. Permasalahan yang terjadi pada akhirnya berdampak pada tidak tercapainya tujuan perusahaan seperti pemenuhan kepuasan pelanggan dan penurunan profit perusahaan. Tujuan penelitian untuk mendeteksi dan mengidentifikasi permasalahan yang terjadi pada PT. XYZ serta mengimplementasikan solusi. Metode penelitian melalui teknik open system dengan menggunakan metode kualitatif. Hasil penelitian menunjukkan tidak adanya kamus kompetensi pada PT. XYZ mengakibatkan pengaruh signifikan terhadap belum optimalnya pengelolaan sumber daya manusia. PT. XYZ ini belum memiliki kamus kompetensi yang dapat digunakan sebagai acuan untuk menggerakan setiap tugas dan tanggung jawab yang ada di perusahaan. Hasil Evaluasi implementasi penyusunan role competency yang dilakukan evaluator PT.XYZ menilai bahwa panduan, hasil role competency dan alat ukur kompetensi telah sesuai dengan kebutuhan organisasi PT. XYZ
\end{abstract}

Kata Kunci: assesment, kompetensi, organisasi. 


\section{PENDAHULUAN}

PT. XYZ di bawah merek XYZ global adalah industri alat berat di Indonesia. Pada awal berdirinya, PT. XYZ merupakan perusahaan gabungan antara PT UT (sekarang distributor resmi produk XYZ di Indonesia) dan XYZ Ltd di Jepang. Kemunculan PT. XYZ juga dipengaruhi oleh maraknya pembangunan infrastruktur di Indonesia dan kepemimpinan UT di pasar alat konstruksi pada saat itu.

Tahun 2011 sampai dengan 2015 usaha pertambangan khususnya batubara lesu yang berdampak pada pembelian alat berat namun pada akhir September 2016 keadaan pertambangan membaik dan pada awal tahun 2017 banyaknya proyek infrastruktur yang digencarkan pemerintah, sehingga mendorong penjualan alat berat hingga pertengahan tahun 2017. Terutama, alat berat yang dijual UT. Secara nasional penjualan alat berat dari awal tahun hingga semester pertama mampu menyamai penjualan selama 2016 kemarin. Sebanyak 2.500 unit, dan terbanyak berada di wilayah Kalimantan, di proyek penambangan batu bara. Penjualan alat berat yang terserap di sektor pertambangan batu bara lebih dari $70 \%$. Hal ini tidak lepas karena membaiknya sektor pertambangan batu bara.

Di sisi lain peningkatan permintaan pasar yang cukup tinggi dari tahun sebelumnya membuat PT. XYZ dalam pemenuhan target produksi bekerja lebih ekstra dengan cara karyawan yang ada harus bekerja lembur lebih banyak dari waktu sebelumnya untuk memenuhi target yang diharapkan baik secara kuantitas maupun kualitas. Namun berbagai masalah muncul seiring dengan meningkatnya permintaan produksi unit PT. XYZ.

Berdasarkan hasil wawancara awal dengan beberapa karyawan PT. XYZ didapatkan bahwa pada proses penyesuaian terhadap perubahan ini PT. XYZ dihadapkan beberapa gejalagejala permasalahan diantaranya belum puasnya konsumen terhadap kualitas unit yang 
dihasilkan, munculnya keluhan karyawan terkait dengan pekerjaan diluar tugas dan tanggung jawab jabatannya, sehingga mereka merasa terbebani.

Hasil data survey kepuasan karyawan (employee satisfaction survey) pada tahun 2015 pada aspek program pengembangan dan penilaian kinerja mendapatkan nilai 10 poin dibawah standar kepuasan yang sudah ditentukan. Hal ini mengindikasikan bahwa belum puas terhadap program pengembangan dan penilaian kinerja dari perusahaan. Pada kuantitas pun pada beberapa waktu masih terjadi keterlambatan waktu pemenuhan dari perjanjian yang telah disepakati. Hal tersebut mengindikasikan bahwa kondisi perusahaan saat ini mengalami gejalagejala yang kontra produktif dengan tujuan organisasi seperti munculnya keluhan karyawan terhadap tugas di luar deskripsi tugas, hubungan atasan yang kurang baik, ketidakpuasan konsumen terhadap produk yang dihasilkan serta masih banyaknya reject rasio di atas $1 \%$ selama tahun fiskal 2016. Beberapa hal tersebut pada akhirnya dapat berdampak pada tidak tercapainya pencapaian tujuan-tujuan perusahaan seperti pemenuhan kepuasan pelanggan yang secara tidak langsung akan menurunkan profit perusahaan.

Hasibuan (2011) memberikan pengertian organisasi sebagai berikut: Organisasi adalah suatu sistem perserikatan formal, berstruktur, dan terkoordinasi dari sekelompok orang yang bekerja sama dalam mencapai tujuan tertentu. Organisasi adalah sekelompok orang yang masuk dalam suatu wadah untuk sebuah tujuan bersama. Organisasi pada dasarnya digunakan sebagai tempat atau wadah orang-orang berkumpul, bekerja secara bersama-sama secara rasional dan sistematis, terencana, terorganisir, terpimpin, serta terkendali dalam memanfaatkan sumber daya yang ada seperti, uang, materil, mesin, metode, lingkungan dan sebagainya. Selain itu sara prasarana, data, dan sebagainya juga digunakan secara efisien dan efektif dalam mencapai tujuan organisasi (Marliani, 2015). 
Upaya peningkatan produksi tentunya memerlukan manajemen produksi yang efektif. Manajemen produksi yang efektif ini akan membantu perusahaan menerapkan proses produksi secara efisien dan berkualitas tinggi untuk menghasilkan produk yang unggul. Beberapa hal utama yang perlu dipersiapkan adalah bahan baku dari suplier yang akan dipakai pada proses produksi. Bahan baku ini akan diubah oleh sumber daya perusahaan dimana sumber daya manusia merupakan motor penggerak utama mengolah bahan mentah menjadi produk jadi. Selain kuantitas dari sumber daya manusia, perusahaan perlu memiliki kualitas kemampuan SDM yang kompeten dalam melakukan proses di perusahaan. Sumberdaya lain yang juga tidak kalah penting adalah fasilitas dan teknologi yang diperlukan perusahaan agar tercapainya target yang telah ditetapkan. Hal ini sejalan dengan hasil penelitian Susilowati Y, Hutagaol P, Pasaribu B dan Djohar S, (2013) yang mengatakan bahwa aspek pengelolaan SDM terbukti berpengaruh positif secara langsung dan signifikan terhadap kinerja organisasi.

Organisasi yang berhasil akan cepat melangkah, mampu untuk mengambangkan produkproduk barunya secara cepat dan mengirimnya ke pasar dengan segera. Dengan kata lain, mereka akan menjadi fleksibel dan akan memerlukan tenaga kerja yang sama fleksibelnya serta bersifat responsif (Robbins, 2015).

Kurt Lewin (dalam Dessler, 2010) telah memformulasikan penjelasan klasik dari bagaimana mengimplementasikan perubahan organisasi dalam menghadapi resistensi yang terjadi. Bagi Lewin (Dessler, 2010), semua perilaku dalam organisasi adalah produk dari dua jenis kekuatan, mereka yang berjuang mempertahankan status quo dan mereka yang mendorong perubahan

Sebelum merencanakan perubahan, terlebih dahulu organisasi harus mampu mendiagnosis permasalahan yang terjadi di dalam organisasi dan intervensi yang diperlukan. Janicijevic (2010) menyatakan diagnosa organisasi adalah suatu metode yang digunakan untuk 
menganalisis organisasi dalam rangka mengidentifikasi kelemahan organisasi sehingga dapat dinetralisasi melalui perubahan organisasi. Mulai dari mengumpulkan informasi tentang masalah, keprihatinan, dan perubahan yang diperlukan oleh anggota organisasi. Menurut Alderer (1980) tujuan dari diagnosa organisasi adalah untuk menetapkan pemahaman yang menyeluruh mengenai suatu sistem dan menjadikannya sebagai dasar dalam menentukan perubahan apa yang diinginkan.

\section{METODE PENELITIAN}

Pemetaan mengenai kondisi organisasi dan gambaran mengenai permasalahan organisasasi diperlukan agar dapat dijadikan dasar dalam melakukan pengembangan organisasi pada PT. XYZ. Oleh karena itu untuk keperluan pemetaan organisasi ini diperlukan tindakan assesment dalam melihat permasalahan yang ada secara mendalam yang didukung dengan analisis diganosa yang tepat. Oleh karena itu teknik diagnosa yang digunakan dalam proses diagnosis organisasi ini adalah teknik diagnosa open system menggunakan medote kualitatif.

Tabel 1. Matriks Diagnosis

\begin{tabular}{|c|c|c|c|c|}
\hline \multirow[t]{2}{*}{ ASPEK } & \multicolumn{4}{|c|}{ Metode Asesmen } \\
\hline & Wawancara & Observasi & $\begin{array}{c}\text { Studi } \\
\text { Dokumen }\end{array}$ & $\begin{array}{c}\text { Catatan } \\
\text { Lapangan }\end{array}$ \\
\hline \multicolumn{5}{|l|}{ Input } \\
\hline General Environment & $\sqrt{ }$ & & $\sqrt{ }$ & \\
\hline Task Environment & $\sqrt{ }$ & & $\sqrt{ }$ & \\
\hline \multicolumn{5}{|l|}{ Komponen Desain } \\
\hline Strategi & $\sqrt{ }$ & & $\sqrt{ }$ & $\sqrt{ }$ \\
\hline Teknologi & $\sqrt{ }$ & & & $\sqrt{ }$ \\
\hline Sistem Pengukuran & $\sqrt{ }$ & & $\sqrt{ }$ & $\sqrt{ }$ \\
\hline Manajemen SDM & $\sqrt{ }$ & & $\sqrt{ }$ & $\sqrt{ }$ \\
\hline Budaya Organisasi & $\sqrt{ }$ & $\sqrt{ }$ & $\sqrt{ }$ & $\sqrt{ }$ \\
\hline \multicolumn{5}{|l|}{ Output } \\
\hline Produktifitas \& Kinerja & $\sqrt{ }$ & & $\sqrt{ }$ & \\
\hline Kinerja Keuangan & $\sqrt{ }$ & & $\sqrt{ }$ & \\
\hline Kepuasan Stakeholder & $\sqrt{ }$ & & $\sqrt{ }$ & \\
\hline Human Outcome & $\sqrt{ }$ & $\sqrt{ }$ & $\sqrt{ }$ & \\
\hline Subjective Outcome & $\sqrt{ }$ & & $\sqrt{ }$ & \\
\hline
\end{tabular}




\section{HASIL PENELITIAN}

Berdasarkan hasil assesment permasalahan dengan menggunakan open system model diagnosis, menunjukan bahwa pengelolaan sumber daya manusia PT. XYZ belum sistematis dan belum terintegrasi akibatnya kurang mendukung tujuan organisasi. Perusahaan hingga saat ini belum memiliki rumusan baku kompetensi sehingga berdampak pada tidak terarahnya implementasi ke HR-an di perusahaan mulai dari rekrutmen, pengembangan hingga penilaian kinerja. Selama ini pengelolaan sumber daya manusia mengacu kepada filosofi perusahaan A, namun untuk pelaksanaanya dasar dan infrastuktur seperti kompetensi tidak dimiliki oleh PT. XYZ. Salah satu contohnya adalah dampak terhadap program pengembangan, selama ini pengembangan hanya didasarkan pada kebutuhan saat ini saja namun hal tersebut belum tentu menjawab kebutuhan organisasi.

Hasil temuan mengungkapkan bahwa saat ini masih belum jelas pengetahuan atau keterampilan apa yang ditingkatkan melalui setiap program pengembangan perusahaan. Hal ini juga dikeluhkan oleh karyawan mengenai materi pengembangan yang diulang. Selain itu karyawan juga merasa terbebani oleh pelaksanaan pelatihan yang berjalan.

Penilaian kinerja tersebut dinilai negatif oleh karyawan karena ketika penilaian tidak ada standar kompetensi yang jelas untuk dinilai khususnya soft competency. Penilaian tersebut meskipun terdapat guide untuk menilai namun menurut karyawan akan sangat dipengaruhi oleh hubungan atasan dengan bawahan. Disisi lain tidak adanya standar soft competency untuk promosi menjadikan orang yang dipromosikan tidak kompeten melakukan pekerjaan bahkan mengundurkan diri setelah diangkat menjadi leader. Berdasarkan analisis diatas, dapat diketahui dengan belum adanya kamus kompetensi pada PT. XYZ mengakibatkan pengaruh signifikan terhadap belum optimalnya pengelolaan sumber daya manusia yang pada akhirnya mempengaruhi tujuan organisasi secara keseluruhan. 


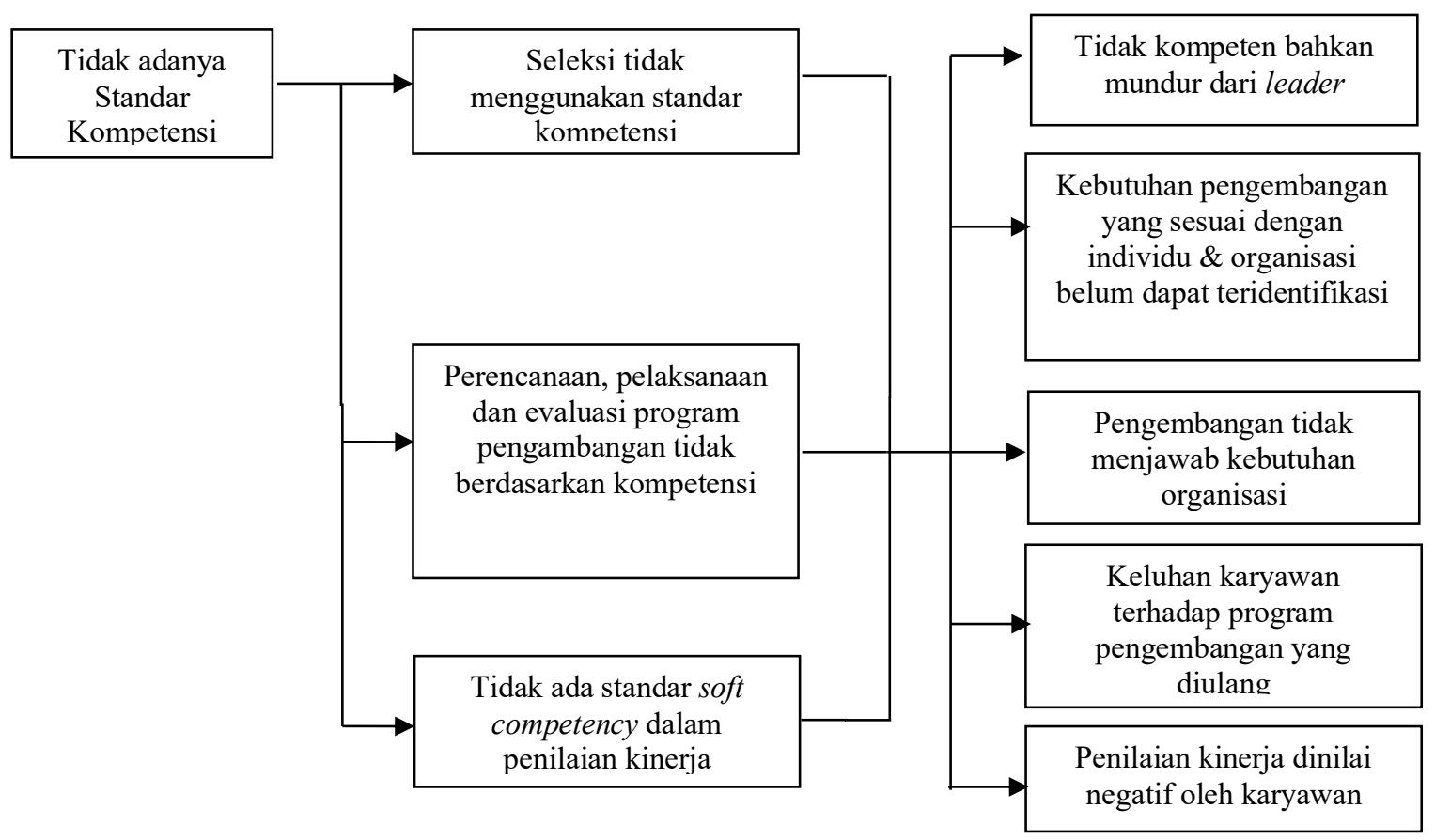

Bagan 1. Kerangka Dinamika Alur Permasalahan Utama

\section{DISKUSI}

PT. XYZ belum memiliki kompetensi yang merata bagi semua jabatan dan hal ini tentu menghambat implementasi ke-HR-an yang ada mulai dari seleksi, pengembangan, penilaian karya hingga reward. Idealnya menurut Byhan dalam Effendi N (2015), subsistem dari kompetensi adalah selection, promotion, training \& development, performance management, and career planning. Oleh sebab itu, peningkatan kinerja manajemen sumberdaya manusia dapat diciptakan melalui integrasi subsistem ini ke dalam sebuah sistem yang lebih besar yang disebut dengan competency-based human resources management (CBHRM).

CBHRM adalah suatu pola pendekatan di dalam membangun suatu sistem manajemen sumberdaya manusia yang handal dengan memanfaatkan kompetensi sebagai titik sentralnya. Mengingat pentingnya keberadaan kompetensi untuk dijadikan acuan maka sudah seharusnya perumusan tersebut segera lengkapi untuk semua jabatan di PT. XYZ. Pengelolaan sumber daya manusia berdasarkan competency-based human resources management (CBHRM) 
diharapkan mampu mengurangi dinamika permasalahan yang terjadi di PT. XYZ, mengingat CBHRM memiliki pengaruh yang sangat signifikan teradap pengelolaan sumber daya manusia dari mulai aspek rekrutmen, pengembangan, penilaian kinerja hingga reward. Adapun dinamika yang diharapkan dapat dikurangi setelah menggunakan CBHRM yaitu :

a. Permasalahan seperti tidak terarahnya impelentasi ke-HR-an akan menjadi lebih terarah dengan kompetensi sebagai landasan dan secara tidak langsung mempengaruhi keluhan beban kerja.

b. Kekurangan man power menjadi lebih maksimal, efektif dan efisien melalui kompetensi secara tidak langsung mempengaruhi rekrutmen manajemen.

c. Hasil pengembangan yang selama ini belum terukur menjadi dapat terukur dengan kompetensi.

d. Penilaian kinerja yang dipersepsikan subjektif menjadi lebih objektif karena menggunakan kompetensi sebagai standar penilaian dan secara tidak langsung mempengaruhi keluhan terhadap reward.

Kompetensi peran adalah kompetensi kegiatan managerial yang dilaksanakan oleh semua pimpinan, dan tidak mencerminkan peran-peran spesialis (Palan, 2008). Penyusunan kompetensi peran (Role competency) menjadi penting atas pertimbangan antara lain :

a. Sampai dengan tahun fiskal 2016 perusahaan belum memiliki role competency sehingga menjadi temuan audit dari TQM.

b. Aspek pengembangan sumber daya manusia pengembangan kompetensi mayoritas masih ke arah fungsional.

c. Kebutuhan guide untuk promosi dan penilaian kinerja ada standar role competency-nya.

d. Penting role competency karena leader mengelola bawahan / sub ordinate yang memiliki karakter dan latar belakang yang berbeda-beda. 
e. Pertimbangan dari aspek compensation \& benefit, hal ini karena leader memiliki tunjangan jabatan namun tidak ada standar kompetensi peran.

f. Pertimbangan aspek organizational development, hal ini karena melalui standar role competency peran antar level jabatan tidak tumpang tindih. Di sisi lain standar kompetensi peran akan menjadi dasar penilaian kinerja, promosi dan mutasi.

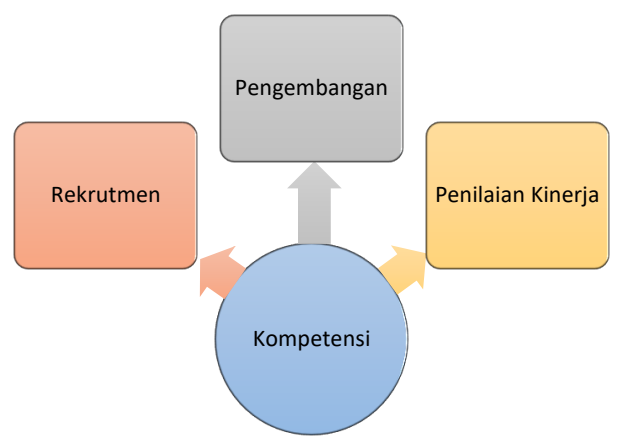

\section{Gambar 1. Implementasi standar kompetensi}

Oleh karena itu salah satu bentuk implementasi dalam Human Resource Management yang dilakukan penulis adalah melakukan membuat menyusun standar kompetensi beserta alat ukurnya. Perumusan impelementasi dengan cara ini bertujuan untuk membentuk desain kompetensi yang terstuktur dan terukur sehingga diharapkan pengelolaan sumber daya manusia mampu mendukung visi dan misi organisasi. Proses penyusunan role managerial competency mengacu kepada tiga tahap penyusunan kompetensi (Palan, 2008) yang telah disesuaikan dengan situasi dan kondisi PT. XYZ. Adapun langkah-langkah penyusunan terbagi ke dalam beberapa proses, yang dapat dlihat pada tabel 2 . 
Tabel 2. Proses Implementasi Penyusunan Role Competency PT.XYZ

\begin{tabular}{|c|c|c|c|}
\hline No. & Tahap & Subtahap & Hasil \\
\hline 1 & Perencanaan & $\begin{array}{l}\text { Rapat, pengumpulan data, } \\
\text { konsultasi internal }\end{array}$ & $\begin{array}{l}\text { Notulen rapat, data-data } \\
\text { PT.XYZ, Guide } \\
\text { assesment, daftar subjek }\end{array}$ \\
\hline 2 & Pengumpulan data & Observasi, wawancara, $F G D$ & $\begin{array}{l}\text { Hasil Observasi, } \\
\text { wawancara, } F G D\end{array}$ \\
\hline 3 & Analisis data & Teknik analisis data \& Rapat & $\begin{array}{l}\text { Tabel tuntutan perilaku, } \\
\text { matriks tuntutan } \\
\text { perilaku, draft judul } \\
\text { kompetensi, draft judul } \\
\text { berdasarkan kelompok } \\
\text { komptensi, }\end{array}$ \\
\hline 4 & Draft kompetensi & Rapat HR & Draft Kompetensi \\
\hline 5 & Validasi kompetensi & Paired Comparison & $\begin{array}{l}\text { Hasil } \\
\text { Comparison }\end{array}$ \\
\hline 6 & $\begin{array}{l}\text { Ratifikasi / pengesahan } \\
\text { kompetensi }\end{array}$ & Rapat Board of director & Model Kompetensi \\
\hline 7 & Alat ukur kompetensi & $\begin{array}{ll}\text { Rapat/FGD HR, rapat/FGD } \\
\text { pimpinan HR, } & \text { rapat/FGD } \\
\text { BOD } & \end{array}$ & $\begin{array}{l}\text { Notulen, Draft alat ukur, } \\
\text { penandatanganan model } \\
\text { alat ukur, buku self } \\
\text { assesment }\end{array}$ \\
\hline
\end{tabular}

Berdasarkan hasil wawancara evaluasi implementasi penyusunan role managerial competency didapatkan kesimpulan bahwa ketiga evaluator menilai role competency telah sesuai dengan kebutuhan organisasi PT. XYZ. Hal ini terungkap dari jawaban yang disampaikan antara lain; bahasa yang digunakan pada buku panduan mudah dipahami untuk implementasi, konsep materi dalam buku dipaparkan dengan jelas, buku panduan membantu pekerjaan bagian HR untuk pengelolaan SDM \& implementasi buku panduan telah sesuai dengan management policy serta audit perusahaan induk dimana kompetensi menjadi prioritas untuk pengelolaan SDM.

\section{KESIMPULAN DAN SARAN}

PT. XYZ ini belum memiliki kamus kompetensi yang dapat digunakan sebagai acuan untuk menggerakan setiap tugas dan tanggung jawab yang ada di perusahaan. Kompetensi yang 
terintegrasi untuk semua aspak MSDM akan membuat pengelolaan sumber daya manusia lebih efektif dan terukur. Hal ini sejalan dengan yang disampaikan Byhan dalam Effendi N (2015). Subsistem dari kompetensi adalah selection, promotion, training \& development, performance management, and career planning. Oleh sebab itu, peningkatan kinerja manajemen sumberdaya manusia dapat diciptakan melalui integrasi subsistem ini ke dalam sebuah sistem yang lebih besar yang disebut dengan competency-based human resources management (CBHRM).

CBHRM adalah suatu pola pendekatan di dalam membangun suatu sistem manajemen sumberdaya manusia yang handal dengan memanfaatkan kompetensi sebagai titik sentralnya. Penyusunan kompetensi peran yang dilakukan dirasa tepat karena telah disesuaikan dengan urgenitas perusahaan di bidang sumber daya manusia yang masih belum memiliki kamus kompetensi di dalam organisasi

\section{DAFTAR PUSTAKA}

Alderer, C.P. (1980). The Methodology of organizational diagnosis. Professional Psichology Vol. 11 No. 3 June 1980. American Psichological Association, Inc

Cummings, T.G., \& Worley, C.G. (2008). Organization Development and Change. Ohio: Thomson Corporation.

Dessler, G. (2010). Manajemen Sumber Daya Manusia. Jakarta: Indeks

Effendi N. (2015). Pengembangan Sumber Daya Manusia Berbasis Kompetensi. Media. Neliti.com (MIMBAR). (Vol. 31, No. 1 (Juni, 2015): 1 -10

Hasibuan, Malayu S.P., (2011). Manajemen Sumber Daya Manusia. Bumi Aksara, Jakarta

Janicijevic, N. (2010). Bussiness Processes in Organizational Diagnosis. Management, Vol. $15,2010,2$, pp. 85-106.

Marliani, R. (2015).Psikologi Industri dan Organisasi.Bandung:Pustaka Setia

Palan. (2008). Competency management (teknik mengimplementasikan manajemen SDM berbasis kompetensi untuk meningkatkan daya saing organisasi. Jakarta; PPM

Robbins, P. S. \& T. A. Judge. (2015). Perilaku Organisasi (Edisi 16). Jakarta: Salemba Empat.

Susilowati Y, Hutagaol P, Pasaribu B, Djohar S. (2013). Pengaruh Aspek Pengelolaan Sumber Daya Manusia terhadap Peningkatan Kinerja Organisasi di Industri Otomotif di Indonesia. Bandung. Jurnal Manajemen Teknologi ITB.

Thoha, M. (2002). Perilaku Organisasi Konsep Dasar dan Aplikasinya. Jakarta: Rajawali Grafindo Persada. 
PSYCHE: JURNAL PSIKOLOGI UNIVERSITAS MUHAMMADIYAH LAMPUNG ISSN (electronic) 2655-6936

Vol. 2 No.2, Agustus 2020 
PSYCHE: JURNAL PSIKOLOGI UNIVERSITAS MUHAMMADIYAH LAMPUNG

ISSN (electronic) 2655-6936 ISSN (printed) 2686-0430 